Journal of Medical Genetics (1975). 12, 138.

\title{
Alpha-feto-protein during development and in disease
}

\author{
ANNA ADINOLFI,* M. ADINOLFI, and M. H. LESSOF \\ Paediatric Research Unit and Department of Medicine, Guy's Hospital Medical School, London SE1 9RT
}

In fetal life, as the tissues develop and mature, a variety of biochemical modifications occur. There is a switch from the synthesis of a number of specific proteins and cellular antigens to the production of other substances with similar biological properties but a different structure. Some proteins and specific antigens are synthesized predominantly during particular phases of development. These are usually referred to as phase-specific antigens (PSA).

Current interest in phase-specific antigens has been stimulated by observations on the biochemical changes which occur in certain forms of cancer and other diseases. These changes may lead to the synthesis, in adult life, of proteins or other antigens which are otherwise produced mainly during the early stages of development. Studies of the mode of activation of the genes which control the synthesis of phase-specific antigens are therefore of great biological interest in clinical medicine. It is now evident that the detection of PSA may also provide important clinical information regarding the diagnosis of tumours and in monitoring progress and response to therapy.

The concept that cancer and embryonic cells have much in common is an old idea. The morphological resemblance between cancer cells and the cells of fetal tissues has been repeatedly discussed in the pathological literature. In 1932, Hirszfeld and his collaborators published the first immunological data suggesting a relationship between tumour and embryonic antigens. More recently, Prehn (1967a; 1967b) was able to show that the growth of syngeneic tumour transplants could be inhibited by previous immunization with embryonic tissues. This work has now been expanded to other tumours induced by viruses or by chemicals (Anderson and Coggin, $1971 ; 1972$ ), and interesting similarities be-

\footnotetext{
Received 25 July 1974.

* Present address: Istituto Internazionale di Genetica e Biofisica, CNR, Napoli, Italy.
}

tween tumour and embryonic cells have also been detected using plant agglutinins (Marx, 1974). The thesis that cancer is a disease of the mechanism of differentiation is strongly supported by the relationship between teratogenesis and oncogenesis.

In recent years, a human fetal plasma protein (alpha- $ᄋ$ feto-protein, AFP) has been found to be presentin high concentration in many patients with primary hepatic $c$ tumours or with teratoblastoma. The detection of this protein has become a well-recognized aid to the diagnosis of these diseases (Abelev, 1971; Masseyeff, 1972; Abelev, 1973). Several fetal antigens other than AFP have also been found to be produced by cancer cells. Some are released in the circulation and others are mainly expressed on the cell surface (Alexander, 1972). This paper will analyse some of the biological and physicochemical properties of AFP, one of the first phase-specific antigens to be associated with cancer. It will also discuss how the estimation of AFP in amniotic fluid may help in the diagnosis of specific fetal malformation or fetal distress.

\section{Methods of detection}

Several immunological techniques have been used to detect and measure AFP in human sera, $\delta$ each with its own advantages (Table I). By immunoelectrophoresis the AFP appears as a line of 을 precipitation in the $\alpha_{1}$-globulin region (Fig. 1). Counter-current, cross-over electrophoresis (Kohn, 음 1970) provides a rapid and sensitive method for the demonstration of concentrations higher than $250 \mathrm{ng} / \sigma$ $\mathrm{ml}$. The 'rocket technique' or electroimmuno- N diffusion (Laurell, 1966) has been shown to be N capable of detecting $0.5-1.0 \mu \mathrm{g} / \mathrm{ml}$ and two recent $O$ modifications have increased its sensitivity to $50 \mathrm{ng} / 2$ ml (Nørgaard-Pedersen, 1973; Alpert et al, 1974). The commercially available radial diffusion tech- $\stackrel{\mathbb{D}}{\rightarrow}$ nique, though less sensitive, can still measure concentrations in excess of $2.5 \mu \mathrm{g} / \mathrm{ml}$. Recently, the 
TABLE I

SOME IMMUNOLOGICAL METHODS FOR THE DETECTION AND ESTIMATION OF AFP*

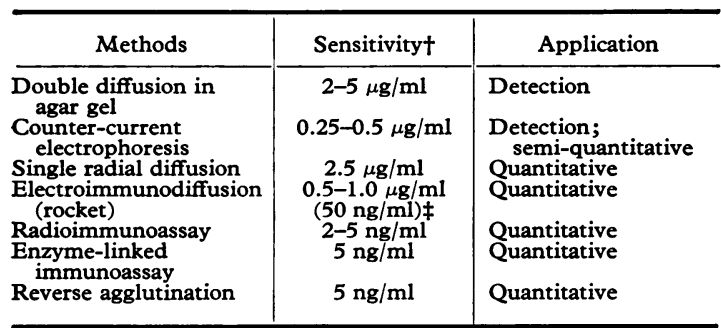

* For references see text.

t Lowest sensitivity using conventional technique.

\# The sensitivity is increased using an immunoradioassay or an immunoperoxidase test.

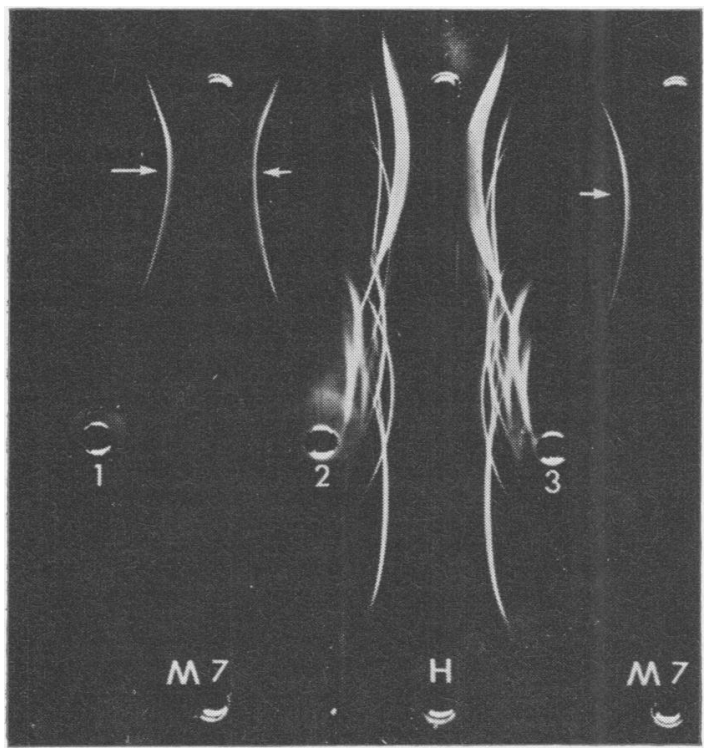

FIG. 1. Immunoelectrophoretic pattern of two cord serum (1 and 2) and a serum from a patient with hepatoma (3) tested against rabbit immune serum against AFP (M7) and horse immune serum against 'adult type' human plasma proteins (H). AFP appears as a line of precipitation in the $\alpha$-globulin region (arrows).

radioimmunoassay method based on the coprecipitation-inhibition of anti-AFP and ${ }^{125}$ I-labelled AFP has been extensively used to measure levels of AFP higher than $2-5 \mathrm{ng} / \mathrm{ml}$.

Other methods include a 'reversed' passive haemagglutination technique (Olovnikof and Tsvetkov, 1969) in which formalin-treated red cells are coated with an antibody which reacts with AFP. In the presence of AFP, agglutination of the treated cells occurs.
An enzyme-linked immunoassay has also been proposed, with a sensitivity which is fully comparable to the radioimmunoassay technique (Bélanger et al, 1973b).

\section{AFP during fetal life and in neonates}

AFP was first detected in the serum of human fetuses less than 5 months old by Bergstrand and Czar $(1956$; 1957) and, using paper electrophoresis, by Halbrecht and Klibanski (1956). Several investigators confirmed these findings (Galdo et al, 1959; Andreoli and Robbins, 1962). Further information about the properties of AFP was obtained only after immunological methods and specific immunosera were introduced (de Muralt and Roulet, 1961; Tatarinov, 1964b; Masopust and Kotal, 1965; Gitlin and Boesman, 1966; Adinolfi and Gardner, 1967; Burtin et al, 1967; Gitlin and Boesman, 1967a; 1967b).

The immunodiffusion techniques provided clear evidence that AFP was present in sera of human fetuses more than 4 weeks old. Levels of the protein in the serum increase rapidly during the next 4-6 weeks of life in utero, and the highest values have been found at 12 to 16 weeks of gestation (Fig. 2; Gitlin and Boesman, 1966; van Furth and Adinolfi, 1969; Adinolfi, 1971). In the older fetus the level of AFP decreases and in infants at term the concentration ranges between 2 and $17 \mathrm{mg} / 100 \mathrm{ml}$ (Gitlin and Boesman, 1966; Adinolfi and Gardner, 1967; Marklein and Rings, 1972).

After birth, AFP disappears rapidly from the circulation during the first 3 weeks of life. However, levels between 25 and $200 \mathrm{ng} / \mathrm{ml}$ can still be detected in a small percentage of normal infants up to 1 year old (Masseyeff et al, 1974).

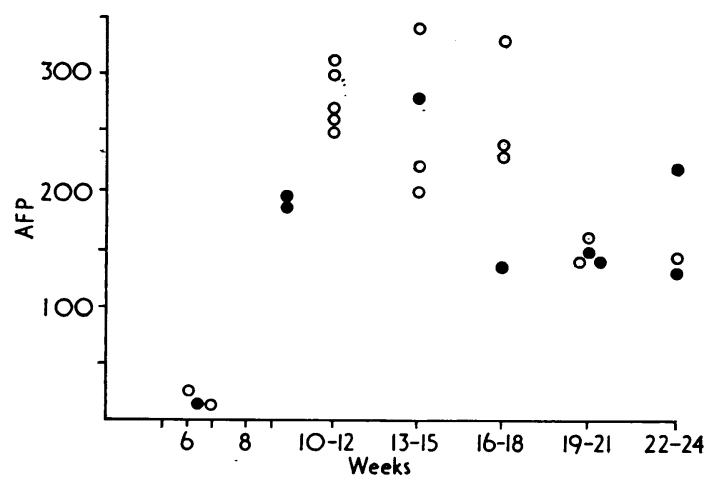

FIG. 2. Individual levels of AFP in sera of human fetuses $(\theta=$ from Gitlin and Boesman, 1966; $O=$ from van Furth and Adinolf, 1969). 
With the introduction of radioimmunoassay methods serum levels between 2 and $20 \mathrm{ng} / \mathrm{ml}$ have also been detected throughout childhood and in normal adults. Male and female blood donors have comparable values (Ruoslahti and Seppälä, 1972; Masseyeff et al, 1974).

Since the amount of AFP decreases during the last trimester of gestation and reaches low levels at term, it has been suggested that the serum values of AFP in fetal blood may reflect the degree of fetal maturity (Bergstrand et al, 1972; Karlsson et al, 1972; Hyvarinen et al, 1973). Since premature infants have a weight that relates to the degree of maturity-ie, the gestational age-it might be expected that such infants would have higher levels of AFP than more mature infants of the same weight. Bergstrand and his colleagues (1972) have shown that the levels of AFP vary significantly with the degree of maturity. They found no statistically significant differences between full-term infants, whatever their size, but infants at term tended to have lower levels of AFP than premature infants. According to Bergstrand et al (1972) AFP levels gave a closer correlation with the gestational age than did birth weight, serum albumin or the total serum protein level. On the other hand Lardinois et al (1972) have not observed a correlation between gestational age and levels of AFP.

\section{AFP in amniotic fluid}

Using immunodiffusion methods, traces of AFP were first detected in apparently normal human amniotic fluid by Gitlin and Boesman (1966) and by Adinolfi and Gardner (1967) and Seppälä et al (1967). This finding has been confirmed (Brock and Sutcliffe, 1972) though the reported levels have varied with the standards used.

In amniotic fluid from normal pregnancies, the mean values of AFP are as follows: between 10 and 14 weeks $\overline{\mathrm{x}}=20 \mu \mathrm{g} / \mathrm{ml}$ (range 4 to $36 \mu \mathrm{g} / \mathrm{ml}$ ); between 15 and 18 weeks $\bar{x}=15 \mu \mathrm{g} / \mathrm{ml}$ (range 4 to $32 \mu \mathrm{g} / \mathrm{ml}$ ), and between 19 and 22 weeks $\overline{\mathrm{x}}=6.5 \mu \mathrm{g} /$ $\mathrm{ml}$ (range 2 to $16 \mu \mathrm{g} / \mathrm{ml}$ ). These estimations need to be confirmed using a large group of normal pregnancies, and also using an international standard for the estimation of AFP, which is now available from the International Agency for Research on Cancer, Lyon, France.

AFP has also been detected in meconium and in the urine, cerebrospinal fluid, and bile of the human fetus.

\section{AFP in normal pregnant women}

The question of whether AFP crosses the placenta has been the subject of controversy. In 1959,
Bodman described the presence of a fetal $\alpha$-globulin in normal pregnant women and in 1964, Tatarinov (1964b) detected AFP in sera of a high percentage of women after spontaneous abortion.

Using an immunodiffusion technique, Foy and his collaborators $(1970 \mathrm{a} ; 1970 \mathrm{~d})$ were able to detect traces of AFP in about $50 \%$ of normal pregnant women after 30 weeks of gestation. These findings were not confirmed by Alpert and Zuckerman (1970). However, using the counter-current technique, with the lowest limit of detection near 0.25 $\mu \mathrm{g} / \mathrm{ml}$, AFP was detected in normal pregnant women at delivery. The fetal protein was found to disappear from maternal serum within 1 week, suggesting that it was derived from the fetus (Adinolfi and Kohn, 1971). Although, theoretically, there is an alternative possibility that the hormonal changes of pregnancy might lead to a temporary de-repression of AFP synthesis, it is notable that no rise in AFP has been detected following the hormonal changes induced by the contraceptive pill (Seppälä, 1973a).

High levels of AFP have since been demonstrated in all maternal sera (Fig. 3) from the first trimester of gestation (Seppälä and Ruoslahti, 1972; Garoff and Seppälä, 1973). In multiple pregnancies the mean levels of AFP are higher - as they are for placental lactogen-than those present in single pregnancies (Garoff and Seppälä, 1973). Maternal antibodies against AFP have not yet been detected in normal pregnant women either by the counter-current technique (Adinolfi and $\mathrm{Kohn}, 1971$ ) or by radioimmunoassay (Seppälä and Ruoslahti, 1972).

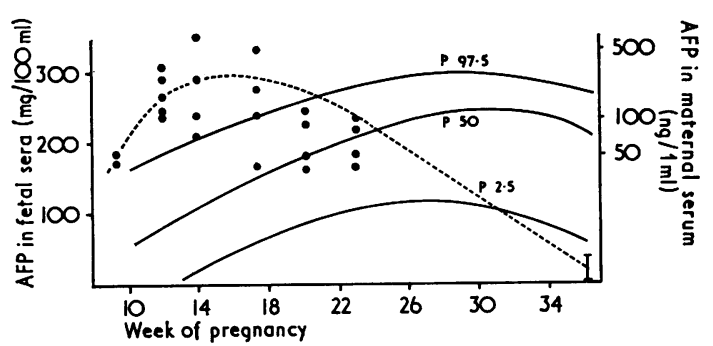

Fig. 3. Levels of AFP ( $\mathrm{mg} / 100 \mathrm{ml}$ ) in sera from human fetuses at various stages of gestation (O) compared with the 97.5, 50, and 2.5 centiles in maternal blood ( $\mathrm{ng} / \mathrm{ml}$ ). The highest values of AFP in fetal and maternal samples are observed at different weeks of pregnancy.

Sites of synthesis and catabolism

The sites of synthesis of AFP have been investigated using in-vitro cultures of fetal tissues in the presence of labelled amino acids. When the culture fluids are harvested and dialysed the presence of newly synthesized proteins can be demonstrated by 


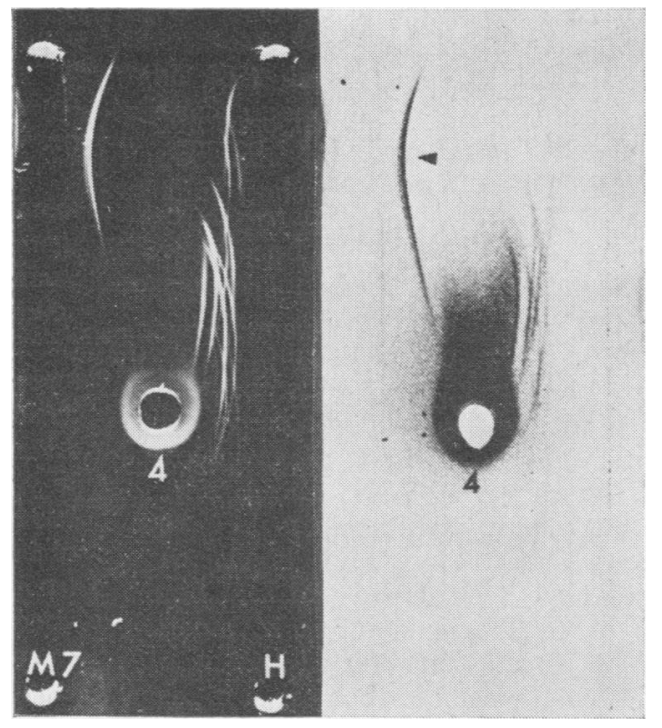

FIG. 4. Immunoelectrophoretic pattern and autoradiography of the liver culture fluid from an 18-week-old fetus. The autoradiography shows the labelled AFP newly synthesized in vitro.

immunoelectrophoresis and autoradiography of the immunoelectrophoretic plates (van Furth and Adinolfi, 1969; Gitlin and Perricelli, 1970). These studies have shown that AFP is synthesized in fetal liver (Fig. 4). The highest rate of synthesis was observed in liver cultures from fetuses of between 10 and 20 weeks of age. In-vitro synthesis of AFP was also observed in the culture fluid of human yolk sac from fetuses between 5.5 and 11.5 weeks old (Gitlin and Perricelli, 1970) and in the human placenta in two out of seven cases which were tested (van Furth and Adinolfi, 1969). Occasionally traces of newly synthesized AFP have also been detected in cultures of fetal gastrointestinal tissues (Gitlin et al, 1972). Newly synthesized AFP has not been detected in the culture fluids of fetal spleen, thymus, or lung tissues.

By studying the incorporation of labelled amino acids into organ cultures of rabbits, newly synthesized AFP has also been detected in cultured placental cells from two 19-day-old fetuses (Branch and Wild, 1972).

Kekomäki and his collaborators (1971) have shown that AFP is produced by the perfused human fetal liver at a rate ranging between 19 and $26 \mu \mathrm{g}$ of AFP $/ \mathrm{min} /$ total liver. The rate of synthesis of albu$\mathrm{min}$ was $50 \mu \mathrm{g} / \mathrm{min}$ at 14 weeks and $196 \mu \mathrm{g} / \mathrm{min}$ at 20 weeks, but during this phase of embryonic life the rate of synthesis of AFP did not seem to vary.

When these data are compared with plasma levels, it appears that AFP has a higher turnover rate than albumin (Gitlin and Boesman, 1966), and that its half life is near 3-5 days at birth. Similar values are obtained when ${ }^{125}$ I-labelled AFP is injected intravenously into the adult patient with a hepatoma (Hirai et al, 1973).

\section{Site of synthesis of AFP at cellular level}

In order to localize the site of production of AFP single fetal cells have been studied using immunofluorescence (Engelhardt et al, 1969; Abelev, 1971; Engelhardt et al, 1971). With this technique AFP was detected almost solely in the liver parenchyma. It is not yet clear if the synthesis occurred in all hepatocytes, nor if other 'adult types' of serum protein were produced in the same cells.

One drawback of the immunofluorescence technique is that it does not discriminate between proteins which are produced by the cell and those which are passively absorbed onto the cell surface, a process which is especially likely to occur with cells such as hepatocytes, which have fragile membranes.

Studies have also been made using antisera against IgG by way of controls. Since it is known that IgG is not produced by liver cells the demonstration of these molecules in the liver tissues would indicate their absorption onto the cell membrane, presumably as a result of membrane damage. When this non-specific effect was excluded it was found that only a small proportion of cancer liver cells shows evidence of synthesizing AFP. The AFP 'positive' cells were detected around capillaries of the tumour sinuses and did not exceed $15 \%$ of the total (Goussev et al, 1970; Engelhardt et al, 1971; Abelev, 1971; Masseyeff, 1972).

Using another approach to the localization of AFP, Uriel and his colleagues (1973) exploited the oestrophilic property of AFP in order to develop an autoradiographic method. Fixed histological sections were taken from rat fetal liver and hepatoma tissues and incubated in solutions of radio-labelled oestrogens. The sections were then washed in order to remove free hormone molecules. Autoradiography showed the localization of the radioactive label in small groups of single, hepatocytelike cells, with some preferential localization in the vicinity of large blood vessels. Haemopoietic, duct, and Küpffer cells were free of radioactivity and were therefore assumed to contain no AFP. In sections of rat hepatoma there were only a few labelled cells disseminated among neoplastic hepatocytes.' These cells were frequently at the border of sinusoid capillaries, suggesting the interesting possibility that in the rat hepatoma the cell type producing AFP is distinct from other neoplastic hepatocytes. 


\section{Structure of AFP}

The data on the physicochemical properties of AFP are still scanty (Table II). Although partial purification of AFP has been achieved by different techniques, contamination with albumin has presented a major problem. It can, however, be separated from other serum proteins by precipitation with ammonium sulphate at between 40 and $65 \%$ saturation. This procedure is normally followed by gel filtration on Sephadex G 150 and DEAE chromatography. Several modifications of this method have been published (Masopust et al, 1971b), but none avoids contamination with traces of albumin and $\alpha_{1}-$ globulin. Isolation by immunochemical methods has, however, been achieved by Nishi (1970), Adinolfi et al (1971), Nishi and Hirai (1971), Ruoslahti and Seppälä (1971), and Hirai et al (1973).

TABLE II

SOME PHYSICOCHEMICAL PROPERTIES OF HUMAN AFP*

\begin{tabular}{|c|c|c|}
\hline & From Fetal Sera & $\begin{array}{c}\text { From Hepatoma } \\
\text { Sera }\end{array}$ \\
\hline 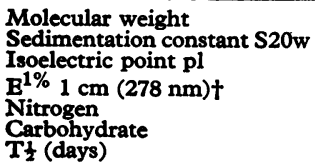 & $\begin{array}{c}64.000 \\
4.50 \\
4.70 \\
5.30 \\
14.70 \\
3 . \overline{50}\end{array}$ & $\begin{array}{r}64.000 \\
4.50 \\
4.70 \\
5.26 \\
14.90 \\
3.40 \\
3.50\end{array}$ \\
\hline
\end{tabular}

- For references see text.

+ Optical density of a $1 \%$ solution in $1-\mathrm{ml}$ cuvette at $278 \mathrm{~nm}$.

There is good agreement that the molecular weight of AFP is near 64000 (Nishi, 1970; Adinolfi et al, 1971; Hirai et al, 1973) and that the protein is formed by a single polypeptide chain (Adinolfi et al, 1971; Ruoslahti and Seppälä, 1971). The carbohydrate content of the protein is near 3.4\% (Hirai et al, 1973). Treatment with neuraminidase slightly reduces the electrophoretic mobility of AFP derived from fetal or hepatoma serum.

AFPS which have been isolated from fetal and hepatoma sera appears to be indistinguishable from one another as judged by immunological tests, molecular weight, amino-acid composition, and the analysis of tryptic digests of the isolated protein (Hirai et al, 1973). A microheterogeneity has, however, been observed when serum samples containing the fetal protein have been analysed by isoelectric agarose electrophoresis (Alpert et al, 1973).

As with other glycoproteins which contain variable amounts of sialic acid residues, it has been suggested that the AFP variants may differ in the amount of sialic acid present in the molecules, possibly as a result of the low activity of sialyl trans- ferase which is found in fetal tissues (Zimmerman and Madappally, 1973).

Smith and Kelleher (1973) have shown that the two variants of human and rat AFP have a different affinity for Concanavalin A and that therefore they can be separated by affinity chromatography.

\section{AFP in other mammals}

The fetal serum of several mammalian species contains an alpha-feto-protein with properties similar to AFP (Gitlin and Boesman, 1967b; Masopust et al, 1971c; Zizkovsky and Masopust, 1974). It has been detected in dog, cat, sheep, horse, cow, monkey, armadillo, rat, mouse, rabbit, opossum, and harbor seal. There is evidence that AFP is present in birds (Gitlin and Kitzes, 1967), and other species have been investigated, including sharks, which have been shown to have an alpha-feto-protein in 'fetal' serum but not in the adult (Gitlin, 1974). In the shark this protein was found to have a molecular weight of about 75000 Daltons and to be synthesized in liver, stomach and, to a lesser extent, in the intestine and yolk sac. Since the earliest mammals seem to have emerged during the period in which the modern order of sharks first appeared -about 180-200 million years ago-it could be argued that an archaic homologue of AFP may well have been present in a common ancestor.

Human AFP was at first considered to be similar to bovine fetuin, a protein which was discovered by Pedersen in 1944. However, since 1956, Bergstrand and Czar have reported a difference in the percentage of the carbohydrate moiety of the two fetal proteins.

Recent studies by Kithier and his colleagues $(1968 ; 1972)$ have shown that bovine fetuses possess a second serum protein that resembles human AFP. Not only is the structure similar but the level of this bovine protein increases in animals that have cancer of the liver. Immune sera which were raised against this bovine AFP were found to react against goat, sheep, and pig AFP. In addition, and in contrast to antisera against bovine fetuin, rabbit antiserum against bovine AFP also reacted against human AFP. This immunological cross-reactivity emphasizes the similarity between the AFP of one species and another.

Nishi, Hirai, and their colleagues (Nishi et al, 1972; Hirai et al, 1973) have shown that rabbits and horses, when injected with human AFP, produce specific antibodies which cross-react with their own homologous AFP. Common antigenic determinants must therefore be present. Attempts to produce antibodies with homologous AFP in rabbits, rats, and dogs were not successful. 
Table III summarizes the cross-reaction of antihuman and anti-rat AFP immunosera tested against fetal sera from several mammalian species (Hirai $e t$ al, 1973).

TABLE III

EVIDENCE OF COMMON ANTIGENIC DETERMINANTS IN HUMAN AND OTHER MAMMALIAN AFP*

\begin{tabular}{|c|c|c|c|c|c|}
\hline \multirow[t]{2}{*}{ Fetal sera } & \multicolumn{3}{|c|}{$\begin{array}{l}\text { Anti-human AFP } \\
\text { Produced in: }\end{array}$} & \multicolumn{2}{|c|}{$\begin{array}{l}\text { Anti-rat AFP } \\
\text { Produced in: }\end{array}$} \\
\hline & Horse & Rabbit & Rat & Horse & Rabbit \\
\hline $\begin{array}{l}\text { Human } \\
\text { Horse } \\
\text { Calf } \\
\text { Sheep } \\
\text { Pig } \\
\text { Rabbit } \\
\text { Dog } \\
\text { Cat } \\
\text { Rat } \\
\text { Mouse }\end{array}$ & $\begin{array}{c}+++ \\
++ \\
(+) \\
(+) \\
+ \\
++ \\
++ \\
++ \\
+ \\
+\end{array}$ & $\begin{array}{c}++ \\
++ \\
(+) \\
(+) \\
+ \\
+ \\
++ \\
++ \\
+ \\
+\end{array}$ & $\begin{array}{c}++ \\
+ \\
+ \\
+ \\
+ \\
+ \\
++ \\
++ \\
=\end{array}$ & $\begin{array}{c}\bar{Z} \\
\bar{z} \\
\bar{z} \\
\overline{++}+ \\
++\end{array}$ & $\begin{array}{c}= \\
\bar{Z} \\
\bar{Z} \\
\bar{Z} \\
+\overline{+}+ \\
++\end{array}$ \\
\hline
\end{tabular}

* Based on the cross-reaction of antisera raised in various species against human or rat AFP. Data from Hirai et al (1973).

\section{Biological function of AFP}

Uriel and his colleagues (1972) have found that some hormones are firmly bound by rat AFP. This seemed to suggest a possible role for this fetal protein in the transport of hormones and in the fetomaternal relationship across the placental barrier. Oestrone, oestradiol, oestriol, and diethylstilboestrol all bind to rat AFP (Uriel et al, 1972; Anssel et al, 1974) regardless of which AFP variant is tested (Belanger and Dufour, 1974).

Swartz et al (1974) were unable to confirm the binding of oestrogens to human AFP. This, conceivably, may have been due to a previous saturation of binding sites with fetal hormones, but it also suggests the possibility that alpha-feto-proteins may have a different role in different species. Indeed in man, oestrogen binding is mainly associated with albumin and $\mathrm{a} \beta$-globulin.

The effect of mouse AFP on primary and secondary antibody response has been investigated by Murgita and Tomasi (1974a; 1974b). Using an in-vitro plaque technique, AFP from amniotic fluid was found to have a non-cytotoxic inhibitory effect on the primary and secondary synthesis of antibodies to sheep red cells. AFP was also found to suppress the mitogenic effect of phytohaemagglutinin, concancavalin A, and lipopolysaccharide on mouse spleen cells and to inhibit allogeneic lymphocyte stimulation in the one-way mixed lymphocyte reaction. These results suggest that AFP may play an important immunoregulatory function in the normal fetal development, the protection of the fetus against the maternal immunological attack and in certain disease states associated with high levels of AFP.

\section{AFP in patients with primary cancer of liver}

Tatarinov (1964a) was the first to make the observation that AFP may be present in the blood of patients with primary cancer of the liver. This, and similar observations in mice (Abelev et al, 1963), prompted a whole series of systematic studies on the incidence of AFP in patients with hepatocellular carcinoma and other diseases of the liver (Abelev, 1965; Kithier et al, 1966; Uriel et al, 1967; Abelev, 1968; Alpert et al, 1968; Masopust et al, 1968; Masseyeff et al, 1968; Purves et al, 1968; Uriel et al, 1968; Alpert, 1969; Alpert et al, 1969; Endo et al, 1969; Foli et al, 1969; Hull et al, 1969b; de Nécheaud et al, 1969; Economopoulas et al, 1970; Foy et al, 1970b; Hull et al, 1970; O'Conor et al, 1970; Purves et al, 1970a; Abelev, 1971; Kresno et al, 1971; Masseyeff, 1972; Purves et al, 1973b).

In various ethnic groups, it has been found that carcinoma of the liver is not always associated with AFP levels in the same proportion of cases. The data reported in Fig. 5 have been obtained using immunodiffusion techniques. When radioimmunoassay methods are used a higher incidence of positive cases is observed but some differences persist between the various ethnic groups. It has been suggested that the fetal AFP gene may be 'activated'

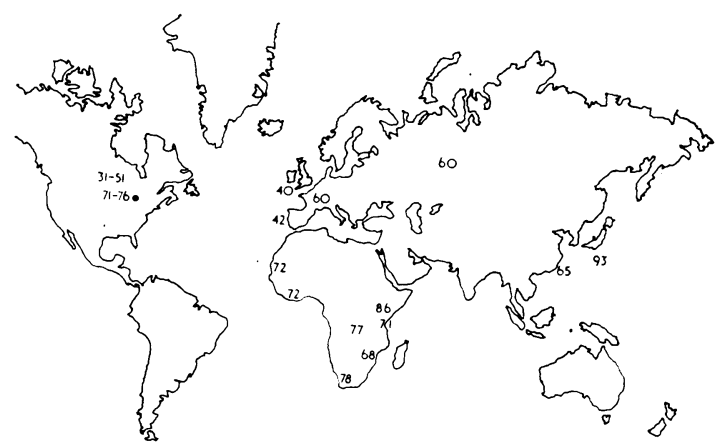

FIG. 5. Percentage of patients with primary carcinoma of liver with high levels of AFP detected by immunodiffusion techniques. Data in USA refer to estimations in Caucasians and Negroes ( $\bullet$ ) by immunodiffusion ( 31 and 71 ) and radioimmunoassay (51 and 76). (For references see text.)

more readily by certain genetic or aetiological factors and at younger ages. Raised levels of AFP are found in the large majority of patients with primary cancer of the liver who are less than 30 years old, but in only about half of patients who are more than 60 
years old Bagshawe and Parker, 1970; Mawas et al, 1970; Masseyeff, 1973). Since the age of onset of the disease varies in different populations, it is possible that the activation of AFP in some patients reflects an earlier onset of the disease in Africans as compared to Caucasians. Independent studies by Purves et al (1973b) and Abelev et al (1974) have also shown that apparently normal individuals in Senegal and Congo may have levels of AFP between 30 and $500 \mu \mathrm{g} / \mathrm{ml}$. Whether these represent 'high-risk' subjects for primary carcinoma of the liver remains to be established. There is good agreement that the presence of AFP in patients with hepatocellular carcinoma is not related to histological differences, the volume of the tumour, or the duration of the disease (Masseyeff et al, 1968; Foli et al, 1969; Purves et al, 1970b).

In several studies raised levels of AFP have been found in a higher percentage of male than female patients (Masseyeff et al, 1968; O'Conor et al, 1970; Alpert et al, 1971; Hull and McIntire, 1972). However, in a group of adult Japanese patients, it was difficult to discern either age or sex differences in the prevalence of AFP or its concentration in serum (Nishi and Hirai, 1973).

In-vitro cultures of liver tissues obtained from cancer patients with high levels of AFP have suggested that this protein is produced exclusively by the liver cancer cells. Normal liver tissue, obtained by biopsy from the same patient, does not synthesise AFP in vitro (Adinolfi and Adinolfi, 1971). There is also evidence to suggest that only between 10 and $20 \%$ of the total liver cancer cells produce and release AFP in vitro (Abelev, 1971).

The serum level of AFP often falls temporarily after the surgical removal of a liver tumour (Masseyeff et al, 1968; Lin, 1970; Mawas et al, 1971). Occasionally, it then reaches a steady level (Alpert et al, 1971), and it may eventually disappear from the circulation. It has been suggested that in these cases incomplete removal of the tumour may leave viable cells which produce AFP, and this appears to be a very good explanation of the persisting steady level. The final disappearance of AFP cannot be explained with such conviction, but it has been suggested that the remaining tumour cells may be rejected by the host cellular immune response. When a disappearance or decrease in the level of AFP is followed by an increase this would indicate a recurrence of the disease.

It is generally agreed that AFP levels are little affected by the agents which are used to treat patients with hepatocellular carcinoma, including methotrexate and cyclophosphamide, radiotherapy, and corticosteroids (Purves et al, 1970b; Lin, 1970).

\section{AFP in patients with terablastoma}

In addition to its presence in patients with primary carcinoma of the liver, high levels of AFP have been detected in many patients with teratoblastoma or embryonal carcinoma of the testis or the ovary. Abelev and his colleagues (1967) found high levels of AFP in 10 out of their 27 patients. These findings have been repeatedly confirmed (Masopust et al, 1968; Mawas et al, 1969; Abelev, 1971; Mawas et al, 1971; Buffe, 1973). Those tumours which are associated with high levels of AFP were found to contain undifferentiated tissues with no indication of an organized structure.

The detection and estimation of AFP in patients with teratoblastoma has a considerable clinical value. After surgical treatment, the levels of AFP decrease to normal values in cases of complete remission, but high levels of AFP reappear in blood in patients who develop metastases. As with primary tumours of the liver, there is a higher incidence of 'positive' AFP findings in the young. Mawas and his colleagues $(1970 ; 1971)$, reported high levels of AFP in $56 \%$ of patients who were less than 15 years old as compared to an incidence of $15 \%$ in an older group of subjects.

The reason why only some of these highly undifferentiated tumours of the testis and the ovary produce AFP is not yet clear; it has been suggested that the synthesis is associated with tumours containing hepatic tissue (Masseyeff, 1972) or vitelline cells (Ballas, 1972). High levels of AFP have not been detected in children with tumours such as neuroblastoma, nephroblastoma, lymphoreticulosarcoma, osteosarcoma, embryonal carcinoma, brain tumours, and liver angioma (Masopust et al, 1968; Mawas et al, 1971; Buffe, 1973).

\section{AFP in experimental cancer of liver}

AFP may be detected not only in human patients but also in adult animals with primary carcinoma of the liver. The first report showing an association between a fetal serum protein and tumour of the liver was that of Abelev and his collaborators (1963), who based their studies on the mouse. Hepatomas which produce AFP can be induced readily in mice and rats and are capable of transplantation. The fetal protein may also be excreted in the urine of hepatoma-bearing rats, as it may in pregnant animals (Okon et al, 1973). Studies in the rat after the administration of carcinogens have shown that on basal diet containing 3'-methyl-4 dimethyl aminobenzene (3'DAB) or dimethyl nitrosamine, AFP may be detected in the serum after only 2 weeks (Watabe, 1971; Kroes et al, 1972; de Néchaud and Uriel, 
1973). Once detected, AFP was found to persist in the blood for some time, regardless of whether the administration of carcinogen continued. Those rats which maintained a stable level of AFP in the serum had a high probability of developing a hepatocellular carcinoma. Of those with cancer, $70 \%$ had detectable AFP.

A fetal plasma protein with some of the characteristics and common antigenic determinants of human AFP has also been observed in cows with primary carcinoma of liver (Kithier et al, 1972). Similar findings have been reported in monkeys (Hull et al, 1969a) after the induction of liver tumours by treatment with $\mathrm{N}$-nitroso-diethylamine (DENA). Adamson et al (1972) have shown that oral DENA induces a liver tumour in $82 \%$ of cases, and $60 \%$ of those which developed a hepatoma also produced AFP. On the other hand, AFP was not found in monkeys who received other types of carcinogens. When the DENA was administered intraperitoneally an even more striking effect was obtained. A hepatoma developed in $95 \%$ of the monkeys after a relatively short latent period of 20.6 months. In this series $97 \%$ had a high serum level of AFP which was usually detectable about 6 months before any histological evidence of tumour could be demonstrated.

Foy and his colleagues (1970c; 1970d) have also observed the synthesis of AFP in baboons maintained on a pyridoxine-free diet for periods varying from one to three years.

\section{AFP in patients with gastrointestinal tumours and liver metastases}

High levels of AFP have occasionally been detected in other groups of patients. Using the most conventional immunological assays, abnormal levels of AFP have not been detected in patients with benign adenocarcinoma, haemangioma, or carcinoma of bile ducts.

Masseyeff et al (1968) were the first to observe abnormal levels of AFP using an immunodiffusion technique in patients with metastatic carcinoma of liver. In two of them, one with an anaplastic form of cancer of the stomach and the second with a pancreatic adenocarcinoma, post-mortem examination demonstrated the presence of metastases of the liver. Abnormal levels of AFP have also been described in patients with secondary cancer of liver (Bourreille et al, 1970; Andrieu et al, 1971; Geffroy et al, 1971).

The occasional presence of high levels of AFP has been recorded in the literature in other isolated cases with or without secondary cancer of the liver, and from these findings it may be concluded that the synthesis of AFP may increase in a few patients with tumours of the stomach or the pancreas in the absence of a primary liver cancer (Bernades et al, 1971).

\section{AFP and fetal alkaline phosphatase}

The association of AFP with other fetal antigens has been the subject of a number of studies. A fetal alkaline phosphatase, characterized by a high heat stability (Regan isoenzyme) has been recognized in adults with cancer. It was first isolated from a patient (Regan) with a bronchial carcinoma. The enzyme is usually present in the placenta and serum of pregnant women, but not in normal adult tissues. The Regan fetal alkaline phosphatase has been detected in the sera of $4 \%$ of patients with a wide variety of different tumours and its detection has been shown to be a reliable guide for the progression or the regression of the carcinoma following treatment.

Another variant of alkaline phosphatase, which differs from the Regan isoenzyme, has been found in human hepatocellular cancer (Warnock and Reisman, 1969). In a study of primary carcinoma of the liver in Africa, $65 \%$ of patients were found to have high levels of AFP and $29 \%$ (all with high levels of AFP) had detectable levels of the alkaline phosphatase variant (Portugal et al, 1970).

\section{AFP and hepatitis}

The first case of a patient with hepatitis and high levels of AFP was described by Alpert et al (1968). Another case was reported by Kresno et al (1970) and Geffroy and his colleagues (1970) demonstrated the transitory presence of AFP in the serum of a third adult with viral hepatitis.

When AFP is estimated by radioimmunoassay, levels between 100 and $500 \mathrm{ng} / \mathrm{ml}$ have been observed in several patients with chronic hepatitis and cirrhosis.

It is now known that the levels of the fetal protein increase above the normal values in a large percentage of patients with viral hepatitis. Using immunoradioautography, Abelev (1971) found abnormal levels in 23 out of 176 patients $(12 \%)$. The level rose between 15 and 30 days after the onset of the disease and returned to normal between 15 and 26 weeks. Raised levels have been found only in $\mathrm{Au}-\mathrm{SH}$ positive patients (Smith, 1971) or independently of the presence of the Australia antigen and antibodies (Akeyama et al, 1972; Ruoslahti and Seppälä, 1972. By studying cryoprecipitates from patients with acute or chronic hepatitis FlorinChristensen et al (1974) have shown that autoantibodies with anti-AFP specificity may also be present. 
Masopust et al (1971a) have shown that the percentage of AFP 'positive' sera is higher in young patients with hepatitis than in adult patients. This finding has been confirmed by other investigators (Buffe and Rimbaut, 1973; Chandra, 1973). The highest levels are found in the most severe cases, and in patients who are in coma it has been noted that when AFP appears in the serum this is followed by recovery (Karvountzis and Redeker, 1974). The suggestion has therefore been made that increased synthesis of AFP may be associated with hepatic regeneration and there is also some evidence for this in experimental animals.

Levels of AFP ranging between 4 and $29 \mathrm{mg} /$ $100 \mathrm{ml}$ were detected in 10 out of 11 infants with neonatal hepatitis; in contrast eight infants with biliary atresia had levels lower than $4 \mathrm{mg} / 100 \mathrm{ml}$ (Zelter et al, 1974). It appears that the compensatory response to neonatal hepatitis by the liver parenchyma is proliferation, retrodifferentiation, and increased synthesis of AFP, while the response to biliary atresia is proliferation of tissue incapable of AFP synthesis. A temporary reappearance of AFP in the serum following treatment with carbon tetrachloride has been noted in mice (Bakirov, 1968), rat (de Néchaud and Uriel, 1971; Perova et al, 1971), and rabbit (Branch, 1972). In mice the increased synthesis of AFP can be induced in nearly $100 \%$ of animals treated with carbon tetrachloride, but the reappearance of AFP in rat and rabbits seems to be age dependent and occurs only in young animals. It has recently become evident that this age-dependent reactivation of the AFP gene is often mirrored in man and that in cancer of liver, as in teratoblastoma or hepatitis, high levels of AFP are more frequently found in young subjects than in old.

Geffroy et al (1971) have described a temporary increase of the value of AFP in one out of seven patients with hemochromatosis. No evidence of a hepatoma was found in any of these cases.

\section{AFP in congenital diseases}

Elevated levels of AFP have been detected in eight patients with hereditary tyrosinaemia (Belanger et al, 1973b; Bélanger, 1973). This inborn error of metabolism, inherited under the control of an autosomal recessive gene, is characterized by a progressive degeneration and cirrhosis of the liver. In two cases reported by Buffe and Rimbaut (1973) the elevated levels of AFP were found only in patients with parallel increased values of blood methionine.

High levels of AFP (from 44 to $2800 \mu \mathrm{g} / \mathrm{ml}$ ) have been detected in all 20 patients with ataxia-telangi- ectasia tested by Waldmann and McIntire (1972). None of the sibs or parents of these patients had levels above normal values. Abnormal concentrations of AFP were not detected in another group of patients with various types of immunodeficiency. These findings have been confirmed by Simons and Hosking (1974). The persistence of AFP in the circulation of patients with ataxia-telangiectasia is connected with the hypothesis that the primary defect in these patients is an abnormality of tissue differentiation.

Using the method of double diffusion in agar gel, a young patient with Down's syndrome was found to have high levels of AFP over a period of 3 years (Adinolfi et al, 1967). However, the possibility that the increased values of AFP were due to a mild form of hepatitis could not be excluded. Subsequent studies using radioimmunoassay (A. Leek and $M$. Adinolfi, unpublished observations) have not revealed abnormal values of the protein in a group of Down's syndrome patients whose ages ranged from 2 to 16 years of age.

Patients with cystic fibrosis (CF) have been found to have levels of AFP ranging from 56 to $8800 \mathrm{ng} / \mathrm{ml}$ (mean 690); a moderate but significant increase in serum AFP was observed in their parents and sibs. Samples from patients with coeliac disease and bronchiectasis had normal values of AFP (Chandra et al, 1975). Persistent synthesis of AFP may be an associated marker of $\mathrm{CF}$ genes and estimation of serum AFP might help to detect heterozygote carriers in families at risk and for prenatal diagnosis of the disease.

\section{Amniotic levels of AFP in neural-tube defects, fetal and placental distress}

Anencephaly, with or without spina bifida, is a relatively common congenital anomaly in many countries. Once an affected child has been produced, the chance that a second child will be affected by the disease is 1 in 20 . This hazard increases to 1 in 10 if two previous children have been affected (Roberts, 1970). Several attempts have been made to detect a 'marker' in the amniotic fluid which would indicate the presence of an affected fetus. The presence in the amniotic fluid of bilirubin or bilirubin-like molecules (with an extinction coefficient near $450 \mathrm{~nm}$ ) has suggested a possible leakage or transudation of fetal blood components.

In 1972, Brock and Sutcliffe published a retrospective study and showed that the level of AFP was increased in the amniotic fluid of the anencephalic fetus between 26 and 36 weeks of gestation. Later, again retrospectively, Brock and Scrimgeour (1972) 
observed a high level of AFP in the amniotic fluid of an anencephalic fetus that was only 18 weeks old. This suggested that the detection of an abnormal level of this protein could be of diagnostic value at an early stage of gestation. Since then anencephaly and spina bifida have been successfully diagnosed in utero on the evidence of a raised level of AFP in the amniotic fluid (Allan et al, 1973; Nevin et al, 1973; Seller et al, 1973; Harris et al, 1974).

Allan et al (1973) have confirmed the value of estimating the levels of AFP in the detection of open neural-tube defects early enough to allow termination of the pregnancy. Spina bifida was detected by amniocentesis in two out of 20 pregnancies at risk because of at least one previous affected child. Low levels of AFP in the amniotic fluid in the presence of fetuses with neutral-tube defects have been observed during the last weeks of gestation when only a small amount of this fetal protein is synthesized by the fetus.

Harris et al (1974) have carried out a prospective study of mothers at risk; they concluded that when amniocentesis and ultrasound are employed to detect fetuses with anencephaly and spina bifida, most cases are detectable before 20 weeks of gestation, thus allowing selective abortion. Closed neural-tube defects, as well as one case of 'open' spina bifida at 33 weeks of gestation, were found to be associated with normal levels of AFP in amniotic fluid.

However, a word of warning is necessary, since raised levels of AFP have been found in the amniotic fluid in the absence of neural-tube defects; raised levels may be associated with the spontaneous abortions, erythroblastosis, and fetal distress (Seppälä and Ruoslahti, 1972; 1973a; 1973b).

In the case of open neural-tube defects it has been suggested that the high levels of AFP in amniotic fluid are due to the transfer of the protein from cerebrospinal fluid (CSF). Levels of AFP ranging from 1220 to $52 \mu \mathrm{g} / \mathrm{ml}$ ) have been detected in the CSF of normal fetuses from 16 to 25 weeks of gestation (Seller and Adinolfi, 1975).

Work is now in progress in several laboratories to evaluate the significance of the levels of AFP in amniotic fluid and in maternal blood. One of the problems concerning amniotic fluid is that it may occasionally be contaminated with fetal blood and so give falsely high readings. It has been calculated (Ward and Stewart, 1974) that a fetal bleed of only $1 \mathrm{ml}$ will produce an abnormally high AFP reading in amniotic fluid at 14 weeks-or less if there is incomplete mixing in the amniotic fluid. Although Harris et al (1974) have not found serum-AFP measurements to be reliable, however, others have obtained useful results, especially in the 13th to 18th week (Brock et al, 1973; Brock and Scimgeour, 1974; Seller et al, 1974; Wald et al, 1974). As with amniotic fluid measurements it is clear that the method may not detect 'closed' neural-tube defects. It also seems likely that anencephaly or open spina bifida will sometimes be missed if reliance is placed on maternal blood measurements alone.

In fact, lack of correlation between the levels of AFP in amniotic fluid and those in the corresponding maternal serum has been repeatedly observed (Adinolfi, 1975; Seppälä, 1975). In several instances, high levels of AFP in amniotic fluid were associated with normal values in maternal serum.

High levels of AFP in maternal sera have also been detected in twin and triplet pregnancies; in twin pregnancies the average AFP levels were double those found in singleton pregnancies matched for maternal age, parity and the time of gestation (Garoff and Seppälä, 1973; Wald et al, 1975). Intrauterine death is frequently associated with abnormal high levels of AFP in the amniotic fluid and the maternal serum. AFP values above the normal 97.5 centile in maternal circulation were observed in 30 out of 51 cases $(59 \%)$ in which the fetus died in utero. Unequivocally raised levels of AFP in maternal serum were seen in four out of 10 cases when the fetus was still alive (Seppälä, 1975).

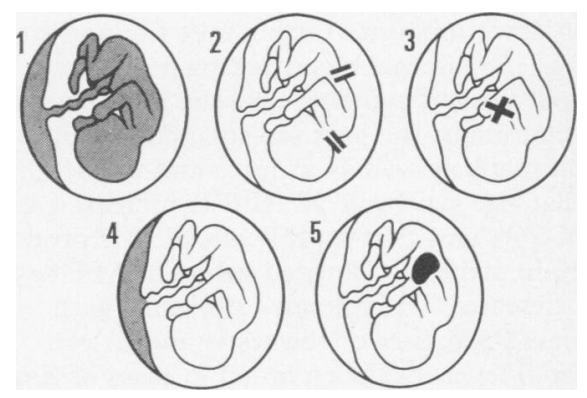

Frg. 6. Possible mechanisms responsible for the increased levels of AFP in amniotic fluid and maternal serum. Fetal death (1) is associated with transendation of AFP in the amniotic fluid and transfer of the protein across the placenta, occasionally even when the fetus is still alive. In 'open' neural-tube defects (2) AFP in amniotic fluid derives from the CSF. Reduced swallowing (3) increases the levels of AFP in amniotic fluid. Placental distress (4), as in diabetic mothers, may be responsible for transfer of AFP in the maternal circulation. Increased synthesis of AFP (5) has been suggested in cases of severe $\mathrm{Rh}$ incompatability.

The raised levels of AFP in amniotic fluid and maternal serum in cases of intra-uterine death are likely to result respectively from the transendation of the protein from the fetus and the placental distress (Fig. 6).

Elevated levels of AFP in amniotic fluid have been observed in fetuses with oesophageal atresia 
(Seppälä, 1973b). Reduced clearance of amniotic fluid by impaired swallowing (Fig. 6) may be responsible for elevated levels of AFP in other fetal abnormalities (Adinolfi, 1975). On the other hand, placental distress may be the major factor responsible for the elevated levels of AFP in maternal blood of diabetic mothers (Fig. 6).

The results of these studies are being compared with other methods for the prenatal detection of congenital malformations, fetal distress, and placental insufficiency. This may help to justify a more widespread screening of pregnant women who are known to have a high risk of carrying a fetus with a neural tube defect.

\section{Summary}

An alpha-feto-protein (AFP) is present in many mammals, in birds, and in sharks during development. The AFP present in different species have similar physicochemical properties and often have common antigenic determinants. Their study, both in health and disease, has provided a useful model for the understanding of other phase-specific antigens and the activation of the genes which control their synthesis.

In the human fetus, the level of AFP falls with increasing maturity. The more sensitive methods of detection have disclosed that this fetal protein persists in trace amounts throughout life and its level increases in maternal blood during pregnancy. The principal sites of synthesis are the fetal liver and in some mammals, the yolk sac splanchnopleur.

In humans as well as in mice and cows, it is notable that the synthesis of AFP is increased in liver cancer cells and that high levels of this protein are present in serum. Elevated values of AFP have also been detected in human subjects with undifferentiated tumours of the testis and ovary. A fall to normal levels has been noted in cases of complete remission after surgery and a return to high levels in patients who develop metastases.

In some patients with hepatitis a temporary rise in the level of AFP has also been observed.

In recent years, the detection of high levels of AFP in amniotic fluid has proved to be of great value for the prenatal diagnosis of neural-tube defects. Abnormal levels have also been found in the amniotic fluid or in maternal serum in cases of spontaneous abortion. Such measurements are now being assessed as a method of monitoring abnormal pregnancy.

The original work by A.A. and M.A. mentioned in this paper was supported by the Spastic Society and the Medical Research Council. A.A. was also the recipient of a travel grant from the Wellcome Trust.
REFBRENCES

Abelev, G. I. (1965). Antigenic structure of chemically-induced hepatomas. Progress in Experimental Tumor Research, 7, 104-157. Abelev, G. I. (1968). Production of embryonal serum alphaglobulin by hepatomas: review of experimental and clinical data. Cancer Research, 28, 1344-1350.

Abelev, G. I. (1971). Alpha-fetoprotein in ontogenesis and its association with malignant tumors. Advances in Cancer Research, 14, 295-358.

Abelev, G. I. (1973). Regulation of alpha-fetoprotein synthesis. Neoplasma, 20, 563-566.

Abelev, G. I., Assecritova, I. V., Kraevsky, N. A., Perova, S. D., and Perevodchikova, N. I. (1967). Embryonal serum $\alpha$-globulin in cancer patients: diagnostic value. International fournal of Cancer, 2, 551-558.

Abelev, G. I., Elgort, D. A., and Perova, S. D. (1974). Quantitative aspects of alpha-fetoprotein synthesis. In Alpha-feto-protein, ed. by R. Masseyeff, pp. 141-171. INSERM, Nice.

Abelev, G. I., Perova, S., Khramkova, N. I., Postnikova, Z. A., and Irlin, I. (1963). Production of embryonal alpha-globulin by the transplantable mouse hepatomas. Transplantation, 1, 174-180.

Adamson, R. H., Smith, C. F., and Dalgard, D. W. (1972). Induction of neoplasma in non-human primates by chemical carcinogens. In Embryonic and Fetal Antigens in Cancer, ed. by N. G. Anderson, J. H. Coggin, E. Cole, and J. W. Holleman, vol. 2, pp. 331-337. Oak Ridge, National Laboratory, Tennessee.

Adinolfii, A. and Adinolfi, M. (1971). Foetal $\alpha-1-$ globulin and its association with hepatocellular carcinoma and teratoblastomas. Ricerca, 1, 316-332.

Adinolfi, A., Adinolfi, M. and Cohen, S. (1971). Isolation and characterization of human foetal- $\alpha$-globulin $\left(\alpha_{1} F\right)$ from foetal and hepatoma sera. Biochimica Biophysica Acta, 251, 197-207.

Adinolfi, M. (1971). Genetic polymorphism and in vitro cultures in studies of the ontogenesis of human fetal proteins. In Biochemistry of Development, ed. by P. F. Benson, pp. 224-247, Clinical Developments in Medicine, No. 37. Heinemann, London.

Adinolfi, M. (1975). On the transfer of $\alpha$-foetoprotein from the foetus into the maternal circulation. In Maternofoetal Transmission of Immunoglobulins-ed. by W. A. Hermmings. (In press.)

Adinolf, M. and Gardner, B. (1967). Studies on the properties of a human fetal serum protein. Developmental Medicine and Child Neurology, 9, 609-616.

Adinolf, M., Gardner, B., and Martin, W. (1967). Fetal proteins and immunoglobulins in Down's syndrome. Atti Associazione Genetica Italiana, 12, 133-143.

Adinolfi, M. and Kohn, J. (1971). Transfer of foetal $\alpha-1-$ globulin into the maternal circulation. In Immunology of Reproduction, pp. 558-560. Bulgarian Academy of Sciences, Sofia.

Akeyama, T., Koyama, T., and Kamada, T. (1972). Alpha-fetoprotein in acute viral hepatitis. New England fournal of Medicine, 287, 989.

Alexander, P. (1972). Foetal 'antigens' in cancer. Nature, 235, 137-140.

Allan, L. D., Ferguson-Smith, M. A., Donald, I., Sweet, E. M., and Gibson, A. A. M. (1973). Amniotic-fluid alpha-fetoprotein in the antenatal diagnosis of spina bifida. Lancet, 2, 522-525.

Alpert, E., Coston, R., and Perrotto, J. (1974). Immunoenzymatic assay for alpha-fetoprotein. Lancet, 1, 626.

Alpert, E., Drysdale, J. W., and Isselbacher, K. J. (1973). Isoelectric focusing of human $\alpha$-fetoprotein an aid in purification and characterization of microheterogeneity. Annals of the New York Academy of Science, 209, 387-396.

Alpert, E., Hershberg, R., Schurr, P. H., and Isselbacher, K. J. (1971). Alpha fetoprotein in human hepatoma: improved detection in serum and quantitative studies using a new sensitive technique. Gastroenterology, 61, 137-143.

Alpert, E., Uriel, J., and Nechaud, B. de (1968). Alpha, fetoglobulin in the diagnosis of human hepatoma. New England fournal of Medicine, 278, 984-986.

Alpert, E. and Zuckerman, J. (1970). Absence of alpha-1-fetoprotein antigen or antibody in maternal sera. Lancet, $2,465$.

Alpert, M. E. (1969). Alpha-1 fetoprotein in human hepatoma. Clinical Research, 17, 461.

Alpert, M. E., Hutt, M. S. R., and Davidson, C. S. (1969). Primary hepatoma in Uganda. American fournal of Medicine, 46, 794-802.

Anderson, N. G. and Coggin, J. H. (1971). Models of differentiation, retrogression and cancer. In Embryonic and Fetal Antigens in Cancer, ed by N. G. Anderson, vol. 1, pp. 7-37. Oak Ridge National Laboratory, Tennessee. 
Anderson, N. G. and Coggin, J. H., Jr. (1972). Retrogenesis: problems and prospects. In Embryonic and Fetal Antigens in Cancer, ed. by N. G. Anderson, J. H. Coggin, E. Cole, and J. W. Holleman, vol. 2, pp. 361-368. Oak Ridge National Laboratory, Tennessee.

Andreoli, M. and Robbins, J. (1962). Serum proteins and thyroxineprotein interaction in early human fetuses. Fournal of Clinical Investigation, 41, 1070-1077.

Andrieu, J., Breart, G., Rodier, B., and Robert, P. E. (1971). A propos de l'existence de l'alpha-1-foetoprotéine en dehors de l'hépatome. Presse Médicale, 79, 1595-1596.

Anssel, C., Uriel, J., and Mercier-Bodard, C. (1974). AFP isolation and estrogen binding properties. In Alpha-feto-protein, ed. by $R$. Masseyeff, pp. 17-23. INSERM, Nice.

Bagshawe, A. and Parker, A. M. (1970). Age distribution of alphafetoprotein in hepatocellular carcinoma. Lancet, 2, 268.

Bakirov, R. D. (1968). Appearance of embryonal serum $\alpha$-globulin in adult mice after inhalation of carbon tetrachloride. Bulletin of Experimental Biology and Medicine, 65 (2), 45-47.

Ballas, M. (1972). Yolk sac carcinoma of the ovary with alpha fetoprotein in serum and ascitic fluid demonstrated by immuroosmophoresis. American fournal of Clinical Pathology, 57, 511-516.

Bélanger, L. (1973). Tyrosinémie héréditaire et alpha-1- foetoprotéimie. Pathologie et Biologie, 21, 457-463.

Bélanger, L., Bélanger, M., Prive, L., Larochelle, J., Tremblay, M., and Aubin, G. (1973a). Tyrosinémie héréditaire et alpha-1foetoprotéimie. Pathologie et Biologie, 21, 449-455.

Belanger, L. and Dufour, D. (1974). Microheterogeneity of rat AFP. In Alpha-feto-protein, ed. by R. Masseyeff. INSERM, Nice.

Belanger, L., Silvestre, C., and Dufour, D. (1973b). Enzymelinked immunoassay for alpha-fetoprotein by competitive and sandwich procedures. Clinica Chimica Acta, 48, 15-18.

Bergstrand, C. G. and Czar, B. (1956). Demonstration of a new protein fraction in serum from the human fetus. Scandinavian fournal of Clinical and Laboratory Investigation, 8, 174.

Bergstrand, C. G. and Czar, B. (1957). Paper electrophoretic study of human fetal serum proteins with demonstration of a new protein fraction. Scandinavian fournal of Clinical and Laboratory Investigation, 9, 277-286.

Bergstrand, C. G., Karlsson, B. W., Lindberg, T., and Ekelund, H. (1972). $\alpha$-Foetoprotein, albumin and total protein in serum from preterm and term infants and small for gestational age infants. Acta Paediatrica Scandinavica, 61, 128-132.

Bernades, P., Smadja, M., Rueff, B., Bonnefond, A., Tursz, T., Martin, E., Bognel, C., Barge, J., and Uriel, J. (1971). Presence de l'alpha-foeto-proteine serique dans quartre cas de cancers digestifs primitifs autres que l'hepatome. Presse Médicale, 79, 1585-1587.

Bodman, J. (1959). Development of foetal proteins. Clinica Chimica Acta, 4, 103-109.

Bourreille, J., Metayer, P., Sauger, F., Matray, F., and Fondimare, A. (1970). Existence d'alpha-foeto-protéine au cours d'un cancer secondaire du foie d'origine gastrique. Presse Médicale, 78, 1277-1278.

Branch, W. R. (1972). The ontogeny of alpha-foetoprotein in the foetal and neonatal rabbit and its experimental induction in adult rabbits. International fournal of Cancer, 10, 451-457.

Branch, W. R. and Wild, A. E. (1972). Localisation and synthesis of $\alpha$-fetoprotein in the rabbit. Zeitschrift für Zellforschung, 135, 501-516.

Brock, D. J. H., Bolton, A. E., and Monaghan, J. M. (1973). Prenatal diagnosis of anencephaly through maternal serum-alphafetoprotein measurement. Lancet, 2, 923-924.

Brock, D. J. H. and Scrimgeour, J. B. (1972). Early prenatal diagnosis of anencephaly. Lancet, 2, 1252-1253.

Brock, D. J. H. and Scrimgeour, J. B. (1974). Alpha-fetoprotein in the prenatal diagnosis of CNS malformations. Lancet, 1, 569.

Brock, D. J. H. and Sutcliffe, R. G. (1972). Alpha-fetoprotein in the antenatal diagnosis of anencephaly and spina bifida. Lancet, 2, 197-199.

Buffe, D. (1973). Fetoproteins and childrens' tumours. In Alphafetoprotein and Hepatoma, ed. by H. Hirai and T. Miyagi. GANN Monograph on Cancer Research, vol. 14, pp. 117-128. University Press of Tokyo.

Buffe, D. and Rimbaut, C. (1973). L' $\alpha 1$-foetoproteine dans les atteintes hépatiques et les maladies metaboliques de l'enfant. Biomédicine, 19, 172-176.

Burtin, P., Kleist, S. von, and Buffé, D. (1967). Etude sur les antigènes foetaux humains. 1. Etude immunoélectrophorétique des antigènes du sérum foetal humain absents du sérum adulte. Bulletin de la Société de Chimie Biologique, 49, 1389-1398.

Chandra, R. K. (1973). Hepatitis antigen and $\alpha$-fetoprotein in neonatal hepatitis. Archives of Disease in Childhood, 48, 157-158.

Chandra, R. K., Madhvankutty, K., and Way, R. C. (1975). Serum $\alpha$-fetoprotein levels in patients with cystic fibrosis and their parents and siblings. British Medical fournal, 1, 714-715.

Economopoulos, P., Theodoropoulos, G., and Sakellaropoulos, N. (1970). Alpha-feto-protein in Greece and France. Lancet, 1, 1337.

Endo, Y., Hono, S., Fujiwava, K., M'Yake, K., Kanetaka, T., Yamanaka, M., Susuki, H., Oda, T., Yoshitoshi, Y., Yuii, T., Yokochi, T., and Mivra, T. (1969) Diagnosis of primary carcinoma of the liver by alpha-feto globulin. Kanzo, 10, 143-146.

Engelhardt, N. V., Goussev, A. I., Shipova, J., Jr., and Abelev, G. I. (1971). Immunofluorescent study of alpha-feto-protein in liver and liver tumours. I. technique of afp localization in tissue sections. International fournal of Cancer, 7, 198-206.

Engelhardt, N. V., Shipova, L. V., Goussev, A. I., Yazova, A. R., and Tergrigorova, E. N. (1969). Immunohistochemical detection of alpha-fetoglobulin on sections of the liver of human embryo and newborn mice. Bulletin of Experimental Biology and Medicine, 65 (12), $62-66$.

Florin-Christensen, A., Roux, M. E. B., and Arana, R. M. (1974). Cryoglobulins in acute and chronic liver diseases. Clinical and Experimental Immunology, 16, 599-605.

Foli, A. K., Sherlock, S., and Adinolfi, M. (1969). Serum alpha-1fetoprotein in patients with liver disease. Lancet, 2, 1267-1269.

Foy, H., Kondi, A., and Linsell, C. A. (1970a). Fetoprotein in pregnant African women. Lancet, 2, 663-664.

Foy, H., Kondi, A., Linsell, C. A., Parker, A. M., and Sizaret, P. (1970b). The alpha-1-protein test in hepatocellular carcinoma. Lancet, 1, 411-412.

Foy, H., Kondi, A., Linsell, C. A., Parker, A. M., and Sizaret, P. (1970c). Positive alpha-1-foetoprotein tests in pyridoxine deprived baboons: relevance to liver carcinoma in Africans. Nature, 225, 952-953.

Foy, H., Kondi, A., Parker, A. M., Stanley, R., and Venning, C. D. (1970d). The alpha fetoprotein test in pregnant women, women on oral contraceptives, newborn babies and pyridoxine-deprived baboons. Lancet, 1, 1336-1337.

Furth, R. van and Adinolfi, M. (1969). In vitro synthesis of the foetal $\alpha_{1}$ globulin in man. Nature, 222, 1296-1299.

Galdo, A., Casado, J. P., and Talavera, R. (1959). Démonstration dans le sérum de foetus humain d'une nouvelle fraction protéique au moyen de l'éctrophorèse sur papier. Archives Francaises de Pediatrie, 16, 954-962.

Garoff, L. and Seppälä, M. (1973). Alpha fetoprotein and human placental lactogen levels in maternal serum in multiple pregnancies. fournal of Obstetrics and Gynaecology of the British Commonwealth, $80,695-700$.

Geffroy, Y., Boureille, J., Denis, P., Colin, R., and Metayer, P. (1971). Bilan d'une recherche systématique de l'alpha-1-foetoprotéine dans 224 hépatopathies. Semaine des Hôpitaux de Paris, 47, 1281-1285.

Geffroy, Y., Denis, P., Colin, R., Sauger, F., Matray, F., and Fondimare, A. (1970). Présence d'alpha-1-foetoprotéine chez l'adulte au cours d'une hépatite virale traitée par corticothérapie. Presse Médicale, 78, 1107-1108.

Gitlin, D. (1974). Phylogeny and ontogeny in the evolution of AFP compared to the emergence of immunoglobulins. In Alpha-fetoprotein ed. by R. Masseyeff, pp. 55-72. INSERM, Nice.

Gitlin, D. and Boesman, M. (1966). Serum alpha-fetoprotein, albumin and $\gamma \mathrm{G}$-globulin in the human conceptus. Fournal of Clinical Investigation, 45, 1826-1838.

Gitlin, D. and Boesman, M. (1967a). Sites of serum alpha-fetoprotein synthesis in the human and in the rat. Fournal of Clinical Investigation, 46, 1010-1016.

Gitlin, D. and Boesman, M. (1967b). Fetus specific serum proteins in several mammals and their relation to human alpha-protein. Comparative Biochemistry and Biology, 21, 327-336.

Gitlin, D. and Kitzes, J. (1967). Synthesis of serum albumin, embryo-specific $\alpha$-globulin and conalbumin by chick yolk sac. Biochimica Biophysica Acta, 147, 334-340.

Gitlin, D. and Perricelli, A. (1970). Synthesis of serum albumin, prealbumin, $\alpha$-foetoprotein, $\alpha_{1}$-antitrypsin and transferrin by the human yolk sac. Nature, 228, 995-997.

Gitlin, D., Perricelli, A. and Gitlin, G. M. (1972). Synthesis of $\alpha-$ fetoprotein by liver, yolk sac, and gastrointestinal tract of human conceptus. Cancer Research, 32, 979-982. 
Goussev, A. I., Engelhardt, N. V., Masseyeff, R., Camain, R., and Basteris, B. (1970). Immunofluorescent study of alpha-fetoprotein in liver and liver tumours. International fournal of Cancer, 7, 207-217.

Halbrecht, I. and Klibanski, C. (1956). Identification of a new normal embryonic haemoglobin. Nature, 178, 794-795.

Harris, R., Jennison, R. F., Barson, A. J., Laurence, K. M., Ruoslahti, E., and Seppälä, M. (1974). Comparison of amniotic-fluid and maternal serum-alpha-fetoprotein levels in the early antenatal diagnosis of spina bifida and anencephaly. Lancet, 1, 429-433.

Hirai, H., Nishi, S., Watabe, H., and Tsukada, Y. (1973). Some chemical, experimental and clinical investigations of $\alpha$-fetoprotein. In Alphafetoprotein and Hepatoma, ed. by $\mathrm{H}$. Hirai and T. Miyagi. GANN Monograph on Cancer Research, vol. 14, pp. 19-33. University Press of Tokyo.

Hirszfeld, L., Halber, W., and Rosenblat, J. (1932). Untersuchungen über Verwandtschaftsreaktionen zwischen embryonal und Krebsgewebe. II. Menschenembryo und Menschenkrebs. Zeitschrift für Immunitätsforschung und Experimentelle Therapie, 75, 209-216.

Hull, E. W., Carbone, P. P., Gitlin, D., O'Gara, R. W., and Kelly, M. G. (1969a). Alpha feto-protein in monkeys with hepatoma. Fournal of the National Cancer Institute, 42, 1035-1044.

Hull, E. W., Carbone, P. P., Moertel, C. G., and O'Conor, G. T. (1970). Serum alpha-fetoprotein in U.S.A. Lancet, 1, 779-780.

Hull, E., Moertel, C., and Carbone, P. (1969b). Serum alpha-fetoprotein (AFP) in cancer patients. Clinical Research, 17, 403.

Hull, E. W. and McIntire, K. R. (1972). Serum alpha fetoprotein in American patients. In Embryonic and Fetal Antigens in Cancer, ed. by N. G. Anderson, J. H. Coggin, E. Cole, and J. W. Holleman, vol. 2, pp. 317-320. Oak Ridge National Laboratory, Tennessee.

Hyvarinen, M., Zeltzer, P., Oh, W., and Stiehm, E. R. (1973). Influence of gestational age on serum levels of alpha-1 fetoprotein, IgG globulin, and albumin in newborn infants. Fournal of Pediatrics, 82, 430-437.

Karlsson, B. W., Bergstrand, C. G., Ekelund, H., and Lindberg, T. (1972). Postnatal changes of alpha-fetoprotein, albumin and total protein in human serum. Acta Paediatrica Scandinavica, 61, 133139.

Karvountzis, G. G. and Redeker, A. G. (1974). Relation of alphafetoprotein in acute hepatitis to severity and prognosis. Annals of Internal Medicine, 80, 156-160.

Kekomäki, M., Seppälä, M., Ehnholm, C. C., Schwartz, A. L., and Raivio, K. (1971). Perfusion of isolated human fetal liver, synthesis and release of $\alpha$-fetoprotein and albumin. International Fournal of Cancer, 8, 250-258.

Kithier, K., Al-Sarraf, M., and Poulik, M. D. (1972). Fetuin and bovine fetoprotein: A comparison. In Embryonic and Fetal Antigens in Cancer, ed. by N. G. Anderson, J. H. Coggin, E. Cole, and J. W. Holleman, vol. 2, pp. 351-354. Oak Ridge National Laboratory, Tennessee.

Kithier, K., Houstek, J., Masopust, J., and Radl, J. (1966). Occurrence of a specific foetal protein in a primary liver carcinoma. Nature, 212, 414.

Kithier, K., Masopust, J., and Rádl, J. (1968). Fetal alpha-globulin of bovine serum differing from fetuin. Biochimica Biophysica Acta, 160, 135-137.

Kohn, J. (1970). Method for the detection and identification of alpha fetoprotein in serum. Fournal of Clinical Pathology, 23, 733-735.

Kresno, S. B., Gandasoebrata, R., and Rümke, P. (1970). Serum alpha-fetoprotein in Indonesia. Lancet, $1,1178$.

Kresno, S. B., Gandasoebrata, R., and Rümke, P. (1971). Serum alpha-fetoprotein in patients with hepatoma from Djakarta. Protides of the Biological Fluids, 18, 243-245.

Kroes, R., Williams, G., and Weisburger, J. H. (1972). Early appearance of serum $\alpha$-fetoprotein during hepatocarcinogenesis as a function of age of rats and extent of treatment with 3 '-methyl-4dimethylaminoazobenzene. Cancer Research, 32, 1526-1532.

Lardinois, R., Anaghostakis, A., Oritz, M. A., and Delisle, M. (1972). Human $\alpha_{1}$-fetoglobulin during the last trimester of gestation. Clinica Chimica Acta, 37, 81-90.

Laurell, C. B. (1966). Quantitative estimation of proteins by electrophoresis in agarose gel containing antibodies. Analytical Biochemistry, 15, 45-52.

Lin, T.-Y. (1970). Primary cancer of the liver. Quadrennial review. Scandinavian fournal of Gastroenterology, 5, Suppl. 6, 223-241.

Marklein, G. and Rings, M. (1972). Quantitative immunologische Bestimmung des Alpha-1-Fetoproteins in Serum reifer und unreifer Neugeborener sowie im Serum von Saüglingen und Kindern. Zeitschrift fur Kinderheilkunde, 113, 327-335.

Marx, J. L. (1974). Biochemistry of cancer cells: focus on the cell surface. Science, 183, 1279-1282.

Masopust, J., Kithier, K., Rádl, J., Koutecký, J., and Kotál, L. (1968). Occurrence of fetoprotein in patients with neoplasms and non-neoplastic diseases. International fournal of Cancer, 3, 364373.

Masopust, J. and Kotal, L. (1965). Fetoprotein immunochemical behaviour of an autonomous fetal component in sera from human fetuses. Annales Paediatrici, 204, 138-140.

Masopust, J., Radl, J., and Houstek, J. (1971a). Occurrence of $\alpha_{1}$ foetoprotein in some infants suffering hepatopathy. Protides of the Biological Fluids, 18, 239-242.

Masopust, J., Tomasova, H., and Kotal, L. (1971b). Some physicochemical characteristics of human $\alpha_{1}$ fetoprotein. Protides of the Biological Fluids, 18, 37-42.

Masopust, J., Zizkovsky, V., and Kithier, K. (1971c). Fetoproteins in different species of mammals. Protides of the Biological Fluids, $18,63-74$.

Masseyeff, R. (1972). Human alpha-feto-protein. Pathologie et Biologie, 20, 703-725.

Masseyeff, R. (1973). Factors of alpha-feto-protein biosynthesis in man. Ricerca, 3, 27-39.

Masseyeff, R., Gilli, G., Krebs, B., Boner, C., and Zrihen, H. (1974). Evolution en fonction de l'age du taux sérique physiologique de l'alpha-foetoproteine chez l'homme et le rat. In Alpha-fetoprotein, ed. by R. Masseyeff, pp. 313-322. INSERM, Nice.

Masseyeff, R., Sankale, M., Onde, M., Menye, A., Camain, R., Quenum, C., Maydat, L., Mattern, P., Ancelle, P., and Leblanc, L. (1968). Valeur de la recherche de l'alpha-1-foetoprotéine sérique pour le diagnostic du cancer primitif du foie. Bulletin de la Société Médicale d'Afrique Noire de Langue Francaise, 13, 537548.

Mawas, C., Buffe, D., and Burtin, P. (1970). Influence of age on alpha-fetoprotein incidence. Lancet, 1, 1292.

Mawas, C., Buffe, D., Schweisguth, O., and Burtin, P. (1971). Alpha-1-fetoprotein and children's cancer. Revue Europeenne d'Etudes Cliniques et Biologiques, 16, 430-435.

Mawas, C., Kohen, M., Lemerle, J., Buffe, D., Schweisguth, O., and Burtin, P. (1969). Serum alpha-1-fetoprotein in children with malignant ovarian or testicular teratomas. Preliminary results. International fournal of Cancer, 4, 76-79.

Muralt, G. de and Roulet, D. L. A. (1961). Etude immunologique des protéines sériques foetales humaines. Helvetica Paediatrica Acta, 16, 517-533.

Murgita, R. A. and Tomasi, T. B. (1975a). Suppression of the immune response by $\alpha$-fetoprotein. I. The effect of mouse $\alpha$ fetoprotein on the primary and secondary antibody response. fournal of Experimental Medicine, 141, 269-286.

Murgita, R. A. and Tomasi, T. B. (1975b). Suppression of the immune response by $\alpha$-fetoprotein. II. The effect of mouse $\alpha$ fetoprotein on mixed lymphocyte reactivity and mitogen-induced lymphocyte transformation. Fournal of Experimental Medicine, $141,440-452$.

Néchaud, B. de and Uriel, J. (1971). Antigènes cellulaires, transitoires du foie de rat. I. sécrétion et synthèse des protéines sériques foeto-spécifiques au cours du développement et de la régéneration hépatiques. International fournal of Cancer, 8, 7180.

Néchaud, B. de and Uriel, J. (1973). Antigènes cellulaires transitoires du foie de rat. III. Mode de réapparition de l' $\alpha$-fetoprotéine au cours de l'hépatocarcinogénèse chimique. International fournal of Cancer, 11, 104-115.

Néchaud, B. de, Economopoulos, P., and Uriel, J. (1969). Fréquence d'apparition des foetoprotéines dans le sérum de malades atteints d'hépatopathies diverse. Presse Médicale, 77, 1945-1947.

Nevin, N. C., Nesbitt, S., and Thompson, W. (1973). Myelocele and alpha-fetoprotein in amniotic fluid. Lancet, 1, 1383.

Nishi, S. (1970). Isolation and characterization of a human fetal $\alpha$-globulin from the sera of fetuses and a hepatoma patient. Cancer Research, 30, 2507-2513.

Nishi, S. and Hirai, H. (1971). Purification and chemical characterization of human alpha-fetoprotein. Protides of the Biological Fluids, 18, 43-47.

Nishi, S. and Hirai, H. (1973). Radioimmunoassay of $\alpha$-fetoprotein in hepatoma, other liver diseases and pregnancy. In Alpha- 
fetoprotein and hepatoma, ed. by H. Hirai and T. Miyaji, pp. 79-87. GANN Monograph on Cancer Research, No. 14, University Press of Tokyo.

Nishi, S., Watabe, H. and Hirai, H. (1972). Production of antibody to homologous $\alpha$-fetoprotein in rabbits, rats and horses by immunization with human $\alpha$-fetoprotein. Fournal of Immunology, $109,957-960$.

Nørgaard-Pedersen, B. (1973). A high sensitive radioimmunoelectrophoretic quantitation of human $\alpha$-fetoprotein. Clinica Chimica Acta, 48, 345-346.

O'Conor, G. T., Tatarinov, Y. S., Abelev, G., and Uriel, J. (1970). A collaborative study for the evaluation of a serologic test for primary liver cancer. Cancer, 25, 1091-1098.

Okon, E. Rosenmann, E., Dishorn, T., and Boss, J. H. (1973). Excretion of alpha-foetoprotein in the urine of pregnant rats and hepatoma-bearing animals. British fournal of Cancer, 27, 362369.

Olovnikov, A. M. and Tsvetkov, B. C. (1969). Detection of the embryonal alpha-globulin by the method of aggregate haemaglutination in the sera of patients with human cancer. Bulletin of Experimental Biology and Medicine, 68 (12), 102-104.

Pedersen, K. (1944). Fetuin, a new globulin isolated from serum. Nature, 154, 575.

Perova, S. D., Elgort, D. A., and Abelev, G. I. (1971). Alphafetoprotein in sera of rats after partial hepatectomy. Biulleten Ekspremental' noi Biologii e Meditsiny, 71, 45-47.

Portugal, M. L., Azevedo, M. S., and Manso, C. (1970). Serum alpha-fetoprotein and variant alkaline phosphatase in human hepato-cellular carcinoma. International fournal of Cancer, 6 , 383-387.

Prehn, R. T. (1967a). The significance of tumour-distinctive histocompatibility antigens. In Cross-reacting Antigens and Neoantigens, ed. by J. J. Trentin, pp. 105-117. Williams and Wilkins, Baltimore.

Prehn, R. T. (1967b). Tumour antigens. In Immunity, Cancer and Chemotherapy, ed. by E. Mihich, pp. 265-279. Academic Press, New York.

Purves, L. R., Bersohn, I., and Geddes, E. W. (1970a). Serum alpha-fetoprotein and primary cancer of liver in man. Cancer, 25, 1261-1270.

Purves, L. R., Bersohn, I., Geddes, E. W., Falkson, G., and Cohen, L. (1970b). Serum alpha-fetoprotein. IV. Effects of chemotherapy and radiotherapy on serum alpha-fetoprotein levels in cases of primary liver cancer. South African Medical fournal, 44, 590-594.

Purves, L. R., Branch, W. R., and Boes, E. G. M. (1973a). Alphafetoprotein as a diagnostic aid. Lancet, 1, 1007.

Purves, L. R., Branch, W. R., Geddes, E. W., Manso, C., and Portugal, M. (1973b). Serum alpha-fetoprotein. VII. The range of apparent serum values in normal people, pregnant women and primary liver cancer high risk populations. Cancer, 31, 578-587.

Purves, L. R., Macnab, M., and Bersohn, I. (1968). Serum alphafetoprotein. I. Immuno-diffusion and immunoassay results in cases of primary cancer of liver. South African Medical fournal, 42, 1138-1141.

Roberts, J. A. F. (1970). An Introduction to Medical Genetics. Oxford University Press, London.

Ruoslahti, E. and Seppälä, M. (1971). Studies of carcino-fetal proteins. Physical and chemical properties of human alpha-fetoprotein. International fournal of Cancer, 7, 218-225.

Ruoslahti, E. and Seppälä, M. (1972). Properties and occurrence of alpha fetoprotein in serum of healthy adults and patients with hepatitis and cancer of the liver. In Embryonic and Fetal Antigens in Cancer, ed. by N. G. Anderson, J. H. Coggin, E. Cole, and J. W Holleman, vol. 2, pp. 345-349. Oak Ridge National Laboratory, Tennessee.

Seller, M. J. and Adinolfi, M. (1975). Levels of albumin, alphafetoprotein and IgG in human fetal CSF. Archives of Disease in Childhood. (In press.)

Seller, M. J., Campbell, S., Coltart, T. M., and Singer, J. D. (1973). Early termination of anencephalic pregnancy after detection by raised alpha-fetoprotein levels. Lancet, $2,73$.

Seller, M. J., Singer, J. D., Coltart, T. M., and Campbell, S. (1974). Maternal serum alpha-fetoprotein levels and prenatal diagnosis of neural-tube defects. Lancet, 1, 428-429.

Seppälä, M. (1973a). Alpha fetoprotein levels in women taking oral contraceptives. International fournal of Fertility, 18, 206-208.

Seppälä, M. (1973b). Increased alpha-fetoprotein in amniotic fluid associated with congenital oesophageal atresia. Obstetrics and Gynecology, 42, 613-624.
Seppälä, M. (1975). Fetal pathophysiology of human alpha fetoprotein. Annals of the New York Academy of Sciences. (In press.)

Seppälä, M. and Ruoslahti, E. (1972). Radioimmunoassay of maternal serum alpha fetoprotein during pregnancy and delivery. American fournal of Obstetrics and Gynecology, 112, 208-212.

Seppälä, M. and Ruoslahti, E. (1973a). Alpha fetoprotein: physiology and pathology during pregnancy and application to antenatal diagnosis. Fournal of Perinatal Medicine, 1, 104-113.

Seppälä, M. and Ruoslahti, E. (1973b). Alpha fetoprotein in maternal serum: a new marker for the detection of fetal distress and intrauterine death. American fournal of Obstetrics and Gynecology, 115, 48-52.

Seppälä, M., Tallberg, T., and Enholm, C. (1967). Studies on embryo-specific proteins. Physiological characteristics of embryospecific alpha-globulin. Annales Medicinae Experimentalis e Biologiae Fenniae, 45, 16-19.

Simons, M. J. and Hosking, C. S. (1974). AFP and ataxia-telangiectasia. Lancet, 1, 1234.

Smith, C. J. and Kelleher, P. C. (1973). $\alpha_{1}$-Fetoprotein: separation of two molecular variants by affinity chromatography with concanavalin A-agarose. Biochimica Biophysica Acta, 317, 231-235.

Smith, J. B. (1971). Occurrence of alpha-fetoprotein in acute viral hepatitis. International fournal of Cancer, 8, 421-424.

Swartz, S. K., Soloff, M. S. and Suriano, R. R. (1974). A comparison of the estrogen binding activity of rat and human AFP. In Alpha-fetoprotein, ed. by R. Masseyeff, pp. 97-108. INSERM, Nice.

Tatarinov, Y. S. (1964a). Detection of embryospecific alphaglobulin in the blood sera of patients with primary liver tumour. Voprosī Meditsinskol̆ Khimiü, 10, 90-91.

Tatarinov, Y. S. (1964b). New data on the specific antigenic components of human blood serum. Voprosȳ Meditsinskoi Khimit, 10, 584-587.

Uriel, J., Aussel, C., Bouillon, D., Nechaud, B. de, and Loisillier, F. (1973). Localization of rat liver $\alpha$-foetoprotein by cell affinity labelling with tritiated oestrogens. Nature New Biology, 244, 190 192.

Uriel, J., Nechaud, B. de, and Dupiers, M. (1972). Estrogenbinding properties of rat, mouse and man fetospecific serum proteins. Demonstration by immuno-autoradiographic methods. Biochemical and Biophysical Research Communications, 46, 11751180.

Uriel, J., Nechaud, B. de, Stanislawski Birencwajg, M., Masseyeff, R., Leblanc, L., Quenum, C., Loisillier, F., and Grabar, P. (1967). Antigènes embryonnaires et cancer du foie chez l'Homme. Association de l'alpha-foetoprotéine sérique avec l'hépatome primarie. Comptes Rendus Hebdomadaires des Séances de l'Académie des Sciences, 265, 75-78.

Uriel, J., Nechaud, B. de, Stanislawski Birencwajg, M., Masseyeff, R., Leblanc, L., Quenum, C., Loisillier, F., and Grabar, P. (1968). Le diagnostic du cancer primaire du foie par des méthodes immunologiques. Presse Médicale, 76, 1415-1417.

Wald, N., Barker, S., Peto, R., Brock, D. J. H. and Bonnar, J. (1975). Maternal serum $\alpha$-fetoprotein levels in multiple pregnancy. British Medical fournal, 1, 651-652.

Wald, N. J., Brock, D. J. H., and Bonnar, J. (1974). Prenatal diagnosis of spina bifida and anencephaly by maternal serum-alphafetoprotein measurement. Lancet, 1, 765-767.

Waldmann, T. A. and McIntire, K. R. (1972). Serum-alpha-fetoprotein levels in patients with ataxia-telengiectasia. Lancet, 2, 1112-1115.

Ward, A. M. and Stewart, C. R. (1974). False-positive results in antenatal diagnosis of neural-tube disorders. Lancet, 2, 345-346. Warnock, M. L. and Reisman, R. (1969). Variant alkaline phosphatase in human hepato cellular cancers. Clinica Chimica Acta, 24, 5-11.

Watabe, H. (1971). Early appearance of embryonic $\alpha$-globulin in rat serum during carcinogenesis with 4-dimethyl-aminoazobenzene. Cancer Research, 31, 1192-1194.

Zelter, P. M., Neerhout, R. C., Fonkalsrud, E. W., and Stiehm, E. R. (1974). Differentiation between neonatal hepatitis and biliary atresia by measuring serum-alpha-fetoprotein. Lancet, 1, 373375.

Zimmerman, E. F. and Madappally, M. M. (1973). Sialyltransferase: regulation of $\alpha$-fetoprotein microheterogeneity during development. Biochemical fournal, 134, 807-810.

Zizkovsky, V. and Masopust, J. (1974). The detection of specific fetal proteins in thirteen mammalian species. In Alpha-fetoprotein, ed. by R. Masseyeff, pp. 125-137. INSERM, Nice. 